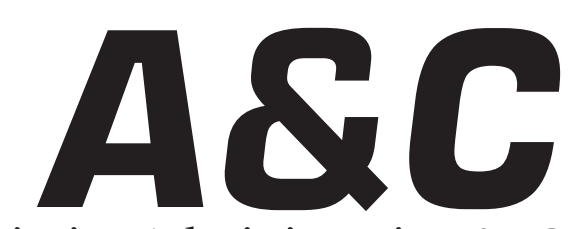

Revista de Direito Administrativo \& Constitucional

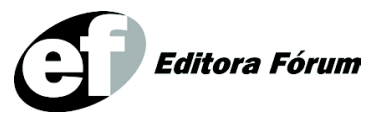

ISSN $1516-3210$ 


\section{A\&C REVISTA DE DIREITO ADMINISTRATIVO E CONSTITUCIONAL}

IPDA

Instituto Paranaense

de Direito Administrativo

Direção Geral

Romeu Felipe Bacellar Filho

Direção Editorial

Paulo Roberto Ferreira Motta

Direção Executiva

Emerson Gabardo

Conselho de Redação

Edgar Chiuratto Guimarães

Adriana da Costa Ricardo Schier

Célio Heitor Guimarães

\section{Conselho Editorial}

Adilson Abreu Dallari

Alice Gonzáles Borges

Carlos Ari Sundfeld

Carlos Ayres Britto

Carlos Delpiazzo

Cármen Lúcia Antunes Rocha

Celso Antônio Bandeira de Mello

Clèmerson Merlin Clève

Clóvis Beznos

Enrique Silva Cimma

Eros Roberto Grau

Fabrício Motta

Guilhermo Andrés Muñoz (in memoriam)

Jaime Rodríguez-Arana Muñoz

Jorge Luís Salomoni

José Carlos Abraão
José Eduardo Martins Cardoso
José Luís Said
José Mario Serrate Paz
Juan Pablo Cajarville Peruffo
Juarez Freitas
Julio Rodolfo Comadira
Luís Enrique Chase Plate
Lúcia Valle Figueiredo
Manoel de Oliveira Franco Sobrinho
(in memoriam)
Marçal Justen Filho
Marcelo Figueiredo
Márcio Cammarosano
Maria Cristina Cesar de Oliveira

Nelson Figueiredo

Odilon Borges Junior

Pascual Caiella

Paulo Eduardo Garrido Modesto

Paulo Henrique Blasi

Paulo Neves de Carvalho (in memoriam)

Paulo Ricardo Schier

Pedro Paulo de Almeida Dutra

Regina Maria Macedo Nery Ferrari

Rogério Gesta Leal

Rolando Pantoja Bauzá

Sérgio Ferraz

Valmir Pontes Filho

Yara Stropa

Weida Zancaner

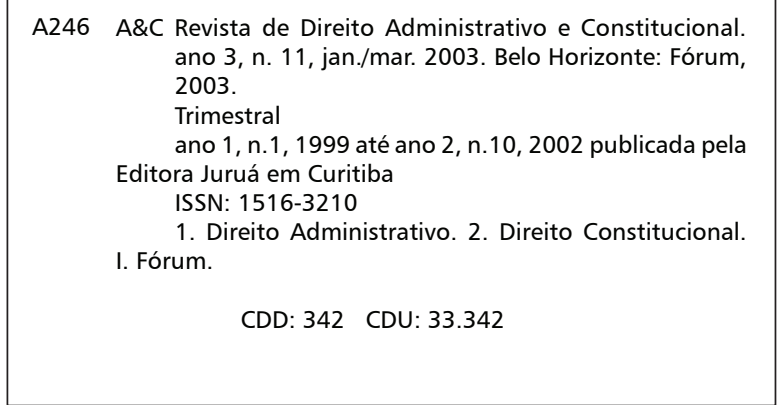

(c) Editora Fórum Ltda. 2006

Todos os direitos reservados. É proibida a reprodução total ou parcial, de qualquer forma ou por qualquer meio eletrônico ou mecânico, inclusive através de processos xerográficos, de fotocópias ou de gravação, sem permissão por escrito do possuidor dos direitos de cópias (Lei $n^{\circ}$ 9.610, de 19.02.1998).

\section{Editora Fórum Ltda}

Av. Afonso Pena, 2770 - 15\%16ªndar - Funcionários

CEP 30130-007 - Belo Horizonte/MG - Brasil

Tel.: 08007043737

Internet: www.editoraforum.com.br

e-mail: editoraforum@editoraforum.com.br
Editor responsável: Luís Cláudio Rodrigues Ferreira Projeto gráfico e diagramação: Luis Alberto Pimenta Revisora: Olga M. A. Sousa

Pesquisa jurídica: Fátima Ribeiro - OAB/MG 74868

Bibliotecária: Alessandra Rodrigues da Silva CRB 2778/MG 6 ${ }^{\text {a Região }}$

Os conceitos e opiniões expressas nos trabalhos assinados são de responsabilidade exclusiva de seus autores.

Impressa no Brasil / Printed in Brazil

Distribuída em todo Território Nacional 


\title{
As cambiantes relações entre o Estado brasileiro e o setor de telefonia
}

\author{
André Felipe Canuto Coelho* \\ Economista. Bacharel em Direito. Mestre em Direito pela UFPE. Doutorando em Ciência Política \\ pela UFPE. Exerce atualmente o cargo de Auditor Fiscal da Receita Federal. Professor de Ciência \\ Política, Direito Administrativo e Direito Econômico.
}

\begin{abstract}
Sumário: Considerações iniciais - 2 A implantação da telefonia numa economia agrário-exportadora - 3 A consolidação dos serviços telefônicos e o Estado burguês - 4 A crise do modelo intervencionista estatal - 5 O colapso de um modelo - 5.1 A flexibilização do monopólio estatal - 5.2 Os ajustes necessários - 5.3 A Lei Geral de Telecomunicações - 5.4 A atuação estatal por meio de uma nova estrutura: a Anatel - 5.5 A telefonia celular e o início da abertura do setor com a venda das concessões da Banda B - 5.6 A reestruturação e a privatização do sistema estatal de telefonia - 6 A privatização como instrumento de passagem do Estado empresário para Estado regulador - Referências
\end{abstract}

Resumo: tratamos nesse estudo do claudicante e difícil percurso da organização dos serviços telefônicos no Brasil. Planeamos uma passagem pelos seus diferentes períodos, evidenciando suas peculiaridades legais, políticas e econômicas, e seus reflexos sobre o momento seguinte. Compomos um panorama desde a introdução da telefonia no Brasil, a sua consolidação nas décadas de sessenta e setenta e posterior estagnação nos anos que se seguiram, finalizando com a revolução implementada a partir da segunda metade dos anos noventa. Por último, traçamos um perfil do Estado que se delineou no setor de telefonia com a mudança de sua atuação na ordem econômica.

Palavras-chave: Telefonia. Privatização. Regulação.

\section{Considerações iniciais}

No final do ano de 2004, a Agência Nacional de Telecomunicações (Anatel) anunciou a marca de mais de 100 milhões de linhas telefônicas em operação no Brasil: 65 milhões utilizando a tecnologia celular e 42 milhões, a tecnologia fixa (MAZZA, 2005). Foram investidos, para a expansão da rede, mais de 80 bilhões de reais, desde o fim da década passada até o presente (DIAS, 2004; COSTA, 2002).

Antecipadamente, cumpriram as empresas de telefonia fixa as metas de atendimento fixadas pela Anatel, gerando-se um estoque de 10 milhões de linhas excedentes. Ainda assim, o cenário para o setor promete: as operadoras do serviço fixo estão focando no mercado corporativo;

\footnotetext{
*E-mail: <afccbgp@uol.com.br>.
}

A \& C R. de Dir. Administrativo e Constitucional, Belo Horizonte, ano 6, n. 25, p. 181-212, jul./set. 2006 
aplicações cada vez mais complexas demandam o aumento contínuo de banda; e serviços inteligentes são implementados para atender exigências crescentes do usuário, como o emprego da tecnologia sem fio (WI-FI) e nova onda da triple $_{\text {play }}{ }^{1}$ (OLIVEIRA; CARVALHO, 2003). Para a telefonia móvel, aposta-se, ainda, num crescimento de $30 \%$ na base de clientes em 2006, enquanto o celular vai se tornando a principal ferramenta de integração do consumidor às suas necessidades transacionais.

Não era essa a realidade num passado ainda recente: em 1998, havia 17 milhões de brasileiros esperando na fila por um telefone fixo e outros 7 milhões à espera de um celular. Dos telefones residenciais existentes naquele ano, 22 milhões de terminais, $81 \%$ ficavam nas mãos dos $16 \%$ mais ricos, enquanto os $57 \%$ mais pobres detinham $2 \%$ das linhas.

A média de linhas telefônicas na classe A era de duas por família, enquanto na classe D havia apenas uma linha para cada cem famílias (POR QUE..., 1998). Registre-se que O investimento médio anual no setor durante os anos 1991-1997 mal alcançou a cifra dos três bilhões de reais, o suficiente apenas para manter a rede existente (PATURY; FERREIRA, 1997).

Nesse entreato, ocorreram mudanças substanciais no mundo jurídico. A Emenda Constitucional $\mathrm{n}^{\circ}$ 08, de 15 de agosto de 1995, pôs fim ao monopólio estatal na prestação dos serviços de telecomunicações e remeteu ao Congresso Nacional a incumbência de votar uma nova legislação para o setor, em substituição ao já envelhecido Código Brasileiro de Telecomunicações (CBT), de 1962. Entrementes, surgiu a Lei Mínima, Lei $\mathrm{n}^{\circ} 9.295 / 96$, que permitiu a concessão a empresas privadas do serviço móvel celular.

Em 16 de julho de 1997, foi promulgada a Lei Geral de Telecomunicações (LGT), Lei n ${ }^{\circ}$ 9.472/97, considerada o grande marco jurídico dessa nova fase, porquanto determinou que o Estado brasileiro deixaria de ser o provedor dos serviços de telecomunicações, passando a regulá-los, com a criação de uma nova estrutura de atuação governamental, a Anatel. Dessa forma, a LGT rompeu com os modelos jurídicos anteriores, mudando conceitos até então vigentes e criando uma nova estrutura de mercado (SUNDFELD, 2000, p. 149).

Esboçamos, neste artigo, um panorama que abordará a introdução da telefonia no Brasil, a sua consolidação nas décadas de 1960 e 1970, bem

\footnotetext{
Tecnologia que permite às operadoras de telefonia, além de transmissão de voz e dados, oferecer serviços de conteúdo de vídeo e uma programação concorrente à das TVs a cabo, por meio de uma conexão banda larga (ABDO, 2005).
}

A \& C R. de Dir. Administrativo e Constitucional, Belo Horizonte, ano 6, n. 25, p. 181-212, jul./set. 2006 
como sua posterior estagnação nos anos que se seguiram, e a revolução implementada a partir da segunda metade dos anos 90 .

Traçamos, por último, um perfil do Estado que se delineou no setor de telefonia com a mudança de sua atuação na ordem econômica. Parodiando ORTIZ (1993, p. 54), constatamos, aqui, que a redução do papel do Estado produtor e financiador foi compensada com um aumento, um novo sentido e uma maior eficácia da sua função reguladora.

\section{A implantação da telefonia numa economia agrário-exportadora}

Ao longo do Império ${ }^{2}$ e durante o primeiro período republicano, que se estendeu até o ano de 1930, o Estado brasileiro não interveio de forma acentuada na economia. Sua maior preocupação era encontrar novas fontes de receitas, atuando, algumas vezes, no comércio exterior com políticas mais ou menos protecionistas.

Com exceção de sua participação no Banco do Brasil — instituição que passou a desempenhar um papel híbrido entre banco comercial e emissor -, nas Caixas Econômicas e na nacionalização gradativa das estradas de ferro, o governo central não se envolveu diretamente em nenhuma outra atividade econômica (BAER, 1980, p. 388-389).

À semelhança das demais economias latino-americanas, a brasileira era tipicamente primário-exportadora, com todo o seu dinamismo dependente não da atuação governamental, mas da demanda pelos seus produtos exportados, sendo bastante vulnerável às crises dos países compradores, como também às variações nos preços internacionais desses produtos (TAVARES, 1972, p. 59).

Foi nesse ambiente que, em 1877, os serviços telefônicos começaram a ser instalados no Brasil. Dois anos depois, foi concedida a primeira autorização para a exploração privada da telefonia nas cidades de Rio de Janeiro e Niterói (BRITO, 1976, p. 29). No entanto, essa exploração comercial somente se efetivou em 1881, com a instalação da Telephone Company of Brazil (MARTINS, 1999, p. 21).

\footnotetext{
2 Nas palavras de Scantimburgo (1996, p. 45): "Um liberal ortodoxo consideraria a política fiscal do Império distante da doutrina, mas tínhamos de promover o desenvolvimento, e a via pela qual o conseguiríamos seria alguma participação fiscal do Estado no favorecimento dos portadores de capitais. Se o liberalismo puro nunca existiu, nos tempos áureos de sua grandeza, no século XIX, não seria no Brasil, onde o mercantilismo mergulhara raízes profundas durante o período colonial, que o teríamos impoluto. Mas, podemos afirmar que o liberalismo tinha predominância sobre o protecionismo".
} 
Em 1881, o governo central passou a deter a competência exclusiva para decidir sobre a outorga desses serviços, com esteio no Decreto $\mathrm{n}^{\mathrm{o}}$ 8.935/1883. Do Rio de Janeiro, a novidade logo se espalhou para São Paulo, Campinas, Florianópolis, Ouro Preto, Curitiba e Fortaleza (ANATEL, (ca. 2000)).

O monopólio da União foi quebrado com a Constituição de 1891, que previa, em seu art. $9^{\circ}, \S 4^{\circ}$, o direito de os estados explorarem linhas telegráficas e, por extensão, linhas telefônicas, entre os diversos pontos de seus territórios, entre estes e os de outros estados que não estivessem servidos por serviços federais. A partir daí, ficou difícil controlar o número de operadoras, os padrões técnicos utilizados, os equipamentos instalados e as políticas tarifárias implementadas.

Ao se permitir, em 1911, que os estados competissem com os serviços que estavam sob a tutela federal, a situação tornou-se "babélica". Não foi por acaso que o Decreto $\mathrm{n}^{\circ} 3.296 / 1917$ modificou a disposição constitucional de 1891: a concessão de serviços telegráficos e telefônicos a empresas privadas, nacionais e estrangeiras, voltava à competência exclusiva da União.

Quatro anos depois, o Decreto $\mathrm{n}^{\mathrm{o}} 4.262 / 1921$ veio restringir a exploração desses serviços às empresas nacionais. Vemos, então, que o modelo de exploração dos serviços de telefonia no Brasil foi marcado, ab initio, por uma confusão normativa, já que o ordenamento jurídico ora permitia, ora não, a exploração por empresas privadas estrangeiras, e ora a União detinha, ora não, a competência exclusiva para autorizá-las (FIORATI, 2004, p. 127).

\section{A consolidação dos serviços telefônicos e o Estado burguês}

A crise da superprodução de café em 1929, a Grande Depressão nos países capitalistas centrais e a Revolução de outubro de 1930 no Brasil produziram mudanças institucionais profundas na condução das políticas governamentais. Seguindo os passos de Oliveira (1981, p. 14), podemos dizer que a Revolução de 1930 representou "[...] o fim da hegemonia agrário-exportadora e o início da predominância da estrutura produtiva de base urbano-industrial".

Nos anos seguintes ao movimento revolucionário, houve uma modificação nas funções e na própria estrutura do Estado brasileiro, criando-se condições para o desenvolvimento, nas palavras de Ianni (1986, p. 25), do 
"Estado burguês", que implicou uma derrota, mas não uma liquidação, do "Estado oligárquico".

Ao longo da década de 1930, o governo central assumiu o Programa do Café, que estava nas mãos das administrações estaduais; implantou uma política cambial favorável às exportações; expandiu a sua atuação em diversos setores produtivos mediante a criação de autarquias; implantou o Código de Água, que lhe autorizava fixar taxas de consumo de eletricidade; criou a Carteira de Crédito Agrícola e Industrial do Banco do Brasil e o Conselho Federal de Comércio Exterior; bem como estatizou o Lloyd brasileiro, principal companhia de navegação do país. ${ }^{3}$

Impende prenotar, aqui, que as relações entre o Estado brasileiro e a economia não foram alteradas de modo completo e abruptamente após a Revolução de 1930. Observamos, todavia, nesse período, um movimento contínuo e sistemático da participação do setor público na condução da economia no país, malgrado as ambigüidades e lutas ideológicas de governantes e empresários (IANNI, 1986, p. 56).

No que concerne ao poder de outorga dos serviços de telefonia, o Estado centralizador que se delineou deu à União a exclusividade na sua prestação. A Constituição de 1934, em seu art. $5^{\circ}$, VIII, manteve, então, a capacidade exclusiva da União em explorar as concessões dos serviços de telefonia, mas previu, no $\S 2^{\circ}$ do mesmo artigo, que os estados poderiam explorar tais serviços para suas finalidades administrativas.

Por sua vez, a Constituição de 1937, art. 15, b, admitiu a possibilidade de os estados legislarem sobre telecomunicações para atender as peculiaridades locais. O resultado foi que, mais uma vez, houve uma multiplicação desordenada dos serviços telefônicos (MARTINS, 1999, p. 25).

No período da II Guerra Mundial (1939-1945), várias empresas governamentais foram criadas, a maioria por questões de segurança nacional. Imbuída desse espírito, e consciente da importância crescente das telecomunicações para a industrialização do país, ${ }^{4}$ a Constituição de 1946 concedeu, em seu art. $5^{\circ}$, XII, disponibilidade exclusiva à União para a concessão dos serviços telefônicos interestaduais e internacionais.

\footnotetext{
3 Para uma discussão mais detalhada desse período, ver Venâncio Filho (1968, p. 358-366).

4 Consoante Furtado (2000, p. 176): "[...] apesar da importância crescente que o setor de telecomunicações vinha assumindo no país, não houve uma política nesse período destinada a fomentá-lo. No governo de Eurico Gaspar Dutra (1946-51) foi implementado o Plano SALTE, que se constituiu em um conjunto de programas econômicos e sociais distribuídos em quatro grandes setores — saúde (S), alimentação (AL), transportes (T) e energia (E), deixando de fora os serviços de telefonia".
} 
Aos estados ficou reservada, por exclusão, a competência para exploração e outorga dos serviços telefônicos em âmbito estadual e municipal. Também aqui não se atentou para o crescimento sem controle do número de operadores de telefonia no país (FIORATI, 2004, p. 127).

Alguns setores da sociedade passaram a ter consciência de tais problemas e assim, em 1947, começou a ser discutida uma codificação para o setor: o projeto do Código Brasileiro de Telecomunicações (CBT). ${ }^{5}$

Enquanto o projeto era maturado no Congresso Nacional, o país atravessava os anos 50, em que uma sucessão de medidas de política econômica buscou modificar a estrutura econômica nacional (LESSA, 1983, p. 20). Assim foi criado, em 1952, o Banco Nacional de Desenvolvimento Econômico (BNDE), para o fornecimento de créditos a longo prazo; em 1953, a Petrobras finalmente saiu do papel e Juscelino Kubtischek (1956-1960) implementou seu auspicioso Plano de Metas, cujo principal objetivo era estabelecer as bases de uma economia industrial madura, com investimentos estatais em infra-estrutura (transporte e energia), estímulo à produção de bens intermediários (aço, carvão) e incentivos à introdução de setores de consumo duráveis de bens de capital (VASCONCELLOS, 1999, p. 238-239).

Segundo Lessa (1983, p. 27, 115) o Plano de Metas consistiu "[...] na mais sólida decisão consciente em prol da industrialização do país”, através da ampliação quantitativa e da mudança qualitativa da sua presença na ordem econômica e "da ordem institucional decorrente do alargamento horizontal e vertical de suas funções".

Em 1962, foi finalmente sancionado o Código Brasileiro de Telecomunicações, na forma da Lei $\mathrm{n}^{\circ} 4.117 / 62$, regulamentada pelo Decreto $\mathrm{n}^{\mathrm{o}} 52.026 / 63$. Por essa época, havia, no país, mais de 1.200 entidades fornecedoras de serviços de telefonia, ${ }^{6}$ dentre elas prefeituras, governos estaduais, empresas privadas e cooperativas, estando o mercado dominado por algumas multinacionais estrangeiras.

A Companhia Telefônica Brasileira (CTB), a Companhia Telefônica Brasileira de Minas Gerais e a Companhia Telefônica Brasileira

\footnotetext{
5 Cf. Martins (1999, p. 27): "[...] tendo ingressado no Congresso Nacional como projeto de Lei para um Código Nacional de Radiodifusão, por pressão das entidades de classe representativas dos radiodifusores brasileiros, incorporou em 1957 os demais serviços de telecomunicações".

6 Número levantado pelo Ministério das Comunicações em 1996 (ANATEL, 1996).
}

A \& C R. de Dir. Administrativo e Constitucional, Belo Horizonte, ano 6, n. 25, p. 181-212, jul./set. 2006 
do Espírito Santo, todas pertencentes à Canadian Tractions Light and Power Company, controlovam 62\% dos telefones instalados no país, numa área que abrangia $45 \%$ da população brasileira.

A Companhia Telefônica Nacional, pertencente à norte-americana International Telegraph and Telephone - IT\&T, explorava o serviço em alguns estados do Nordeste, no Rio Grande do Sul e no Paraná. Nesse ínterim, as ligações entre as regiões do país e as internacionais eram completadas pela inglesa Western Telegraph, pelas norte-americanas Radional e Radiobrás e pela italiana Italcable (NOVAES, 2000, p. 148; VIANNA, 1993, p. 41-42; ANATEL, (ca. 2000)).

O grande número de entidades que operavam sob os mais diferentes padrões tecnológicos e as dificuldades de coordenação entre os diversos estados e a União ocasionaram grandes problemas de interconexão entre as redes: algumas cidades ficavam isoladas, impossibilitadas de se comunicarem com regiões fora da área de atuação de sua companhia telefônica.

Não havia, tampouco, uma política tarifária aplicável uniformemente em todas as localidades, o que fazia com que surgissem dificuldades na cobrança das ligações interurbanas com a imposição de diferentes tarifas aos usuários. Registre-se que, com 1,3 milhão de telefones para uma população de 74 milhões de habitantes, a teledensidade no Brasil, em 1962, restringia-se a 1,7 telefone por 100 habitantes, acrescentando-se a isso o fato de que a maioria das linhas telefônicas estava situada nas grandes capitais do Sudeste do país (MARTINS, 1999, p. 26).

Consciente de todos esses problemas pelos quais o sistema de telefonia estava passando, o legislador buscou, com o Código de 1962, estruturá-lo completamente, de modo a permitir que o Poder Executivo federal centralizasse a sua organização. Estabeleceu regras mais precisas para viabilizar a fiscalização das empresas privadas e do processo de concessão dos serviços; assentou uma política tarifária nacional; buscou a uniformização da infra-estrutura instalada; e permitiu que a União atuasse diretamente como exploradora do serviço (MARTINS, 1999, p. 30).

Uma análise do Código permite destacar várias mudanças: i) atribuiu à União a competência exclusiva para explorar e manter, diretamente, os serviços de telefonia, podendo sua exploração ser feita, quando não executada diretamente, por concessão, autorização e permissão (arts. 10,

A \& C R. de Dir. Administrativo e Constitucional, Belo Horizonte, ano 6, n. 25, p. 181-212, jul./set. 2006 
30, 31, 32 e 33); ${ }^{7}$ ii) classificou os diversos serviços de telecomunicações quanto ao âmbito e à finalidade (arts. $5^{\circ}$ e $6^{\circ}$ ); iii) instituiu o Conselho Nacional de Telecomunicações $(\text { Contel })^{8}$ em seu art. 15; iv) autorizou a União a constituir uma empresa pública para explorar, de forma exclusiva, os serviços de telecomunicações interestaduais: a Embratel (art. 30, § ${ }^{\circ}$ ); v) criou o Fundo Nacional de Telecomunicações (FNT) destinado à ampliação do Sistema Nacional de Telecomunicações (art. 51).

O período de implantação e consolidação do Código Brasileiro de Telecomunicações foi marcado por profundas alterações políticas, econômicas e sociais. Após um intenso crescimento econômico no governo de Juscelino Kubtischek, a economia brasileira entrou em uma fase de retração. Enquanto a taxa de crescimento do produto real caía ano a ano, a inflação subia, alcançando 91,9\% em 1964.

Com a chegada ao poder dos militares pelo golpe de março de 1964, o país foi lentamente trocando o modelo de substituição de importações por um modelo de crescimento econômico associado, o que acentuou a interdependência política e econômica aos centros de decisões do sistema capitalista (FIECHTER, 1972).

Num ambiente dominado pela ideologia da integração e da segurança nacionais, o sistema telefônico brasileiro recebeu um impulso efetivo. Tanto assim que, em setembro de 1965, poucos meses após a entrada em funcionamento da Embratel, todas as capitais do país e suas principais cidades já estavam interligadas.

Em 1966, adquiriu a Embratel as ações que a Canadian Tractions Light and Power Company detinha na Companhia Telefônica Brasileira,

\footnotetext{
7 Apesar de seu art. 34, $2^{\circ}$, dar preferência às pessoas jurídicas de direito público interno na prestação indireta dessas atividades, não se impediu o seu fornecimento por entidades privadas.

8 "O Contel, absorvido posteriormente, em 1967, pelo Ministério das Comunicações, serviu a uma importante função, pois havia a necessidade de um órgão que estabelecesse as regras do setor em um ambiente onde operavam centenas de companhias privadas e estatais. Entre as atribuições do Contel destacavamse: a) aprovar o valor das tarifas a serem cobradas pelas empresas; b) estabelecer as normas, fixar critérios e taxas para redistribuição de tarifas nos casos de tráfego mútuo entre empresas de telecomunicações; c)opinar sobre a outorga, cassação ou renovação de concessões; e d) estabelecer normas técnicas padronizadas que garantissem a eficiente integração dos serviços no sistema nacional de telecomunicações. No que tange às tarifas, o critério adotado estabelecia que o seu valor era fixado de modo a permitir a cobertura das despesas de custeio e prover uma justa remuneração do capital. Este critério acabou levando: a) ao estabelecimento de subsídios cruzados dos serviços de longa distância nacional e internacional para o serviço local; e b) a uma repartição de receita entre a Embratel e as operadoras locais baseada em outros critérios que não os da eficiência econômica. A importância de um órgão regulador foi decrescendo à medida que os serviços de telecomunicações foram sendo incorporados pelo Estado, e não foi por menos que o governo Collor extinguiu o Contel sem maiores conseqüências" (NOVAES, 2000, p. 149).
} 
que dominava o tráfego local de telefonia no Sudeste do país, passando, em 1973, após expirarem os prazos de concessão da Western Telegraph, Radional e Italcable, a explorar sozinha os serviços internacionais (MARTINS, 1999, p. 31).

Nesse rumo, em 1967, a nova Constituição brasileira, em seu art. $8^{\circ}, \mathrm{XV}, a$, atribuiu à União a competência para a exploração direta, ou mediante autorização ou concessão, dos serviços de telecomunicações. ${ }^{9}$ Ainda nesse ano, o Decreto-Lei no 200/67 criou o Ministério das Comunicações em seu art. 35, atribuindo-lhe os serviços de telecomunicações.

De 1969 a 1974, entrou em execução no país o Primeiro Plano Nacional de Desenvolvimento (I PND). Procurando o crescimento econômico e a recolocação do Brasil nos trilhos do desenvolvimento sustentado, o plano apresentava, como uma de suas principais fontes de crescimento, a retomada da inversão estatal nos setores de infra-estrutura, que se tornou possível graças aos recursos advindos da reforma fiscal, de novos mecanismos de endividamento interno e do amplo acesso à poupança externa (CRUZ, 1984). Foi, então, criada, pela Lei no 5.792/72, a Telebras, uma empresa holding estatal que foi absorvendo pouco a pouco as empresas prestadores de serviços de telefonia cujas concessões iam expirando (LEHFELD, 2003, p. 13).

A Embratel e a Telebras desempenharam um papel fundamental na padronização, na unificação e no estabelecimento de um amplo sistema telefônico em todo o território nacional. Conseguindo unificar toda a rede, antes explorada por centenas de entidades públicas e privadas, a União conseguiu auferir as economias de escala próprias de um monopólio natural. ${ }^{10}$

Os terminais telefônicos instalados tiveram um aumento de mais de 500\% num período de 20 anos, posicionando o país entre os detentores das maiores redes de telefonia mundial (LEHFELD, 2003, p. 15). Por outro lado, ao representar sozinhas, a Embratel e a Telebras, um significativo setor da economia nacional, ficou mais fácil a captação de recursos, tanto no mercado interno quanto no internacional (NOVAES, 2000, p. 150).

\footnotetext{
9 Um pouco antes, o Decreto-Lei n 162/67 já havia transferido o poder de outorga de todos os serviços de telecomunicações para a União.

10 "Por força dos arts. $7^{\circ}$ e 10 do CBT, o fundamento econômico do monopólio estatal decorreu da raridade dos meios e das economias de escala, e foi institucionalizado na forma do Sistema Nacional de Telecomunicações, que compreendia os meios - troncos e redes contínuos - através dos quais se executavam os serviços. Tais meios eram de utilização compulsória e mantidos e explorados pela União, através da Empresa Brasileira de Telecomunicações ('Embratel'), constituída inicialmente como empresa pública e posteriormente transformada em sociedade de economia mista" (XAVIER, 2003, p. 27).
} 


\section{A crise do modelo intervencionista estatal}

Tudo parecia encaminhar-se muito bem até que, no final dos anos $70,{ }^{11}$ o Brasil sofreu profundamente as conseqüências do segundo choque do petróleo e do aumento das taxas de juros internacionais.

O início da década seguinte foi marcado pela necessidade de um ajuste profundo nas contas externas, pois o financiamento do grande déficit nas contas correntes do Brasil foi interrompido após a moratória do México em 1982.

Enquanto na primeira metade da década de 1980 o país teve por meta a geração de grandes superávits comerciais, instrumentalizados por fortes desvalorizações cambiais, na segunda metade, ao se diminuir a pressão sobre as contas externas, os políticos voltaram a atenção para a estabilização de preços. A inflação, que se havia elevado nos anos 70, fugiu ao controle na segunda metade do decênio subseqüente, alimentada por um expansivo déficit público e por sofisticados mecanismos de indexação. ${ }^{12}$

Nesse entreato, a política econômica tentou controlar a demanda interna, com diferentes graus de sucesso, para obter equilíbrio externo e, posteriormente, interno. As intervenções diretas nos preços também foram um componente habitual da política econômica, inicialmente com o intuito de aumentar a competitividade dos produtores domésticos e, a partir de 1985, na tentativa de combater a inflação (PINHEIRO; GIAMBIGI, 2000, p. 18). Nos dois casos, recorreu-se às empresas estatais para alcançar objetivos macroeconômicos.

No início da década de 80, o governo central, por meio das empresas estatais, contraiu grandes empréstimos no exterior, o que fez com que a dívida dessas empresas aumentasse consideravelmente com a maxidesvalorização de 1983. Nesse ínterim, o preço dos bens e dos serviços das estatais foi artificialmente reduzido, primeiramente para aumentar a competitividade nas exportações e, depois, para diminuir o impacto nos

\footnotetext{
11 “Em 1981/1989 o PIB 'per capita' subiu 0,3\% ao ano, o déficit público operacional ficou na média em $5,1 \%$ do PIB, a inflação aumentou de 95\% para 1783\% (IGP-DI da Fundação Getúlio Vargas) e os investimentos caíram de $21 \%$ do PIB em 1980/1982 para 17,1\% do PIB em 1987/89, enquanto entravam no país raríssimos investimentos estrangeiros diretos" (PINHEIRO, 2003, p. 3).

12 O Plano Cruzado procurou controlá-la mediante congelamento de preços, mas fracassou em pouco tempo devido à permanência do enorme déficit público, ao aumento excessivo da base monetária e a uma queda de $8 \%$ na produção agrícola. Outros congelamentos de preços, em 1987 e 1989, não tiveram melhor sorte, pois os fundamentos econômicos continuaram a se deteriorar.
} 
índices inflacionários.

Anote-se que, com o fulcro de reduzir a demanda interna, houve uma queda do investimento nas empresas estatais, que diminuiu em quase um terço (1,5\% do PIB) entre 1980/82 e 1987/89. A utilização das estatais como instrumento de política macroeconômica contribuiu sensivelmente para a deterioração da administração dessas empresas ${ }^{13}$ e prejudicou grandemente a qualidade de sua produção (WERNECK, 1993).

Ressaltamos, ainda, que a Constituição de 1988, ao contrário de cobrar das empresas estatais maior eficácia no cumprimento de suas tarefas, proporcionando-lhes os recursos devidos, estatuiu um maior controle sobre elas, impondo-lhes restrições adicionais na sua forma de gestão, o que dificultou sobremaneira uma atuação empresarial competente em mercados cada vez mais exigentes.

A Carta de 1988 ainda submeteu as estatais a longos processos licitatórios para a aquisição de bens e serviços, restringiu-lhes a gestão de pessoal ao limitar salários e exigir concursos públicos, impossibilitou a constituição de subsidiárias ou participação acionária em outra empresa sem prévia aprovação legislativa e sujeitou ao Congresso Nacional a aprovação do seu orçamento de investimentos (FIORATI, 2004, p. 141).

Assim, verifica-se que a Constituição de 1988 consagrou a política governamental de favorecimento à estabilização da economia ao impor, mais uma vez, às empresas estatais restrições para contenção do déficit público, redução do endividamento global e controle do processo inflacionário.

\section{O colapso de um modelo}

\subsection{A flexibilização do monopólio estatal}

Chegamos em 1995 com um setor estatal endividado e com sérios problemas estruturais. O setor de telefonia já passava por profundas mudanças tecnológicas em todo o mundo e havia uma crescente demanda às operadoras pela oferta de serviços ágeis e avançados, o que exigiria vultosos investimentos da Telebras e da Embratel, impossíveis de serem obtidos, devido ao comprometimento de toda a esfera pública com a política fiscal contracionista:

Particularmente após a queda brutal dos investimentos na década de 1980, os setores de infra-estrutura necessitavam seriamente de uma expansão na capacidade instalada, a qual estava além do alcance do setor público, devido

\footnotetext{
${ }^{13}$ Outro grande fator que concorreu para isso foi o aumento da interferência política.
}

A \& C R. de Dir. Administrativo e Constitucional, Belo Horizonte, ano 6, n. 25, p. 181-212, jul./set. 2006 
à crise fiscal, a qual não somente reduziu as transferências de capital para as empresas estatais como também impôs fortes restrições na sua capacidade de investimento, até mesmo quando teria sido possível levantar recursos no mercado. Trazer os investidores privados foi a solução para aumentar os investimentos sem sacrificar a disciplina fiscal. (PINHEIRO, 2003, p. 1)

Complementado o quadro que se descortinava, Campos (1995), ferrenho adversário da atuação do Estado na produção de bens e serviços, apresenta-nos sua visão da estrutura produtiva estatal no Brasil:

- Não há estatais rentáveis para o Tesouro Nacional [...] Dados da Sest e uma análise do balanço dos quatro maiores dinossauros, para o período 1990-93, revelam o seguinte: os dividendos pagos à velha viúva - a União - representam, em média, apenas $1,08 \%$ ao ano [...]. Na realidade, se deduzidos os aportes da União no período, a rentabilidade dos dinossauros se tornaria negativa, em $6,8 \%$ ao ano.

- A diferença entre os dividendos recebidos em 1990-92 e os aportes concedidos e dívidas honradas pelo Tesouro indica que a União teve de pagar US $\$ 1,8$ bilhão pela simples honra de ser proprietária de estatais. Considerando-se que o governo teve de levantar dinheiro no mercado para rolar sua dívida a taxas reais de 20 a $25 \%$ ao ano, percebe-se que as estatais, longe de serem um motor de crescimento, são uma forma de suicídio econômico.

- Dir-se-á que os dinossauros são gigolôs da União e não contribuintes suculentos, constituem um enorme patrimônio. Isso é verdade, mas esse patrimônio só será realizável quando os dinossauros forem privatizados, caso em que o país se beneficiaria de várias formas: a)auferiria caixa com a venda das empresas; b) livrar-se-ia do endividamento, transferindo-o para os particulares; c) passaria a ter lucros pela cobrança do imposto de renda; d) haveria maior capacidade de investimentos e, portanto, de geração de empregos.

\section{A privatização ${ }^{14}$ era alentada às escâncaras como a melhor solução:}

Além de melhorar o caixa governamental, a privatização das companhias telefônicas vai acabar com a obrigação que o governo tem - e cumpre muito mal - de investir nessas empresas. Para o brasileiro, tão maltratado quando o assunto é telefone, a notícia é ótima. Existem hoje 10 milhões de pessoas esperando para comprar um telefone convencional, com fio, e outras 7 milhões na fila pelo celular. Fora aquelas que entraram nos planos de expansão, que já pagaram pelo aparelho e ainda não o receberam. Essa deficiência é resultado do investimento muito pequeno que se tem feito, suficiente apenas para a manutenção do sistema atual. (PATURY; FERREIRA, 1997)

\footnotetext{
${ }^{14}$ A privatização vem assumindo diferentes significados na literatura: (a) transferência total ou parcial dos direitos de propriedade de uma empresa ao setor privado; (b) submissão de empresas estatais às mesmas regras válidas para o setor privado em situação de concorrência por meio de contratos de gestão; e (c) desregulamentação da economia com a finalidade de aumentar a concorrência (PLANE, 1994, p. 45). Na presente abordagem, adotamos o primeiro significado.
} 
O ex-presidente da República, Fernando Henrique Cardoso, não deixou escapar tal realidade, e um de seus motes na campanha presidencial de 1994, "Mãos à obra, Brasil", apregoava a flexibilização do monopólio estatal das telecomunicações por meio de uma emenda constitucional. Por conseguinte, em fevereiro de 1995, iniciou-se o processo de reformulação das comunicações brasileiras, com o envio, ao Congresso Nacional, da Proposta de Emenda Constitucional $\mathrm{n}^{\circ} 03$, que defendia a modificação do art. 21, inc. XI, da Magna Carta. ${ }^{15}$

O art. 21, inc. XI, da Constituição de 1988, em sua versão original, determinava que os serviços de telecomunicações eram serviços públicos a serem prestados em regime de gestão direta, com a faculdade de adoção entre um sistema de gestão integrada ou de gestão personificada, na forma de concessão a empresas sob controle acionário estatal (XAVIER, 2003, p. 28).

A alteração proposta visava a suprimir a expressão "a empresas sob o controle estatal”, permitindo, assim, a outorga a empresas privadas, a critério exclusivo da União, do direito de exploração dos serviços públicos de telecomunicações.

Com a promulgação, no dia 15 de agosto de 1995, da Emenda Constitucional $n^{\circ} 08$ (que veiculou a PEC n ${ }^{\circ} 03$ ), o art. 21 da Constituição de 1988 passou a ter a seguinte redação:

Art. 21. Compete à União:

$[\ldots]$

XI - explorar, diretamente ou mediante autorização, concessão ou permissão, os serviços de telecomunicações, nos termos da lei, que disporá sobre a organização dos serviços, a criação de um órgão regulador e outros aspectos institucionais;

A mais importante inovação da $\mathrm{EC} \mathbf{n}^{\circ}$ 08/95 consistiu na imposição ao legislador infraconstitucional do dever de decidir, com base nos novos pressupostos constitucionais, sobre o modo de organização institucional e de estruturação jurídica do setor econômico das telecomunicações (XAVIER, 2003, p. 29; NOVAES, 2000, p. 169).

Por outro lado, não houve um impacto imediato e efetivo da

\footnotetext{
15 Por ocasião das discussões do Congresso Nacional Constituinte para revogar a Constituição de 1967, a flexibilização do monopólio estatal das telecomunicações foi arduamente defendida na Subcomissão da Comunicação quanto na Comissão Temática VIII. Sobre o assunto verificar Motter (1994).
} 
mudança constitucional, já que caberia a uma lei detalhar o novo papel do Estado no setor. Assim era preciso aguardar todo o trâmite legislativo no Congresso Nacional para que um novo Código de Telecomunicações fosse aprovado.

Percebendo o governo a complexidade de reformar toda a estrutura regulatória do setor a curto prazo, e ainda reticente quanto à necessidade e aos benefícios da venda da Telebras, resolveu cuidar da abertura do Serviço Móvel Celular (SMC) imediatamente. Enviou ao Congresso a chamada Lei Mínima, que possibilitou o leilão da Banda B da telefonia celular. Nesse meio tempo, preparava-se a venda do sistema estatal de telefonia.

Importa lembrar que o sistema estatal de telefonia, em 1995, era composto pela holding Telebras; pela Embratel, que explorava isolada os serviços de longa distância, os serviços de comunicações de dados, de telex e os serviços internacionais; e por 26 subsidiárias, uma para cada estado e uma operadora municipal, que exploravam os serviços locais e a Banda A da telefonia celular.

Essas empresas representavam 95\% da planta de telefonia existentes à época. $\mathrm{O}$ restante, $5 \%$, estava dividido com 4 concessionárias, das quais 3 eram estatais (a CRT, controlada pelo Governo do Estado do Rio Grande do Sul; o SERCOMTEL, pela Prefeitura de Londrina; e a CETERP, pela Prefeitura de Ribeirão Preto) e uma privada (Cia. Telefônica do Brasil Central, no Nordeste de São Paulo e um município de Goiás e um do Mato Grosso do Sul).

É importante assinalar que a União possuía o controle acionário da Telebras com 52,2\% de suas ações ordinárias e 23\% do seu capital total; os investidores estrangeiros detinham cerca de $27 \%$ do capital total da empresa e o restante estava pulverizado entre 5,8 milhões de acionistas (NOVAES, 2000, p. 140-141).

\subsection{Os ajustes necessários}

Foram necessários, no entanto, alguns ajustes antes de se colocar o Sistema Nacional de Telecomunicações à venda. Biondi (2000, p. 7), em afleimados artigos contrários à desestatização ${ }^{16}$ no Brasil, irrompia:

[...] antes das privatizações, o governo já havia começado a aumentar as tarifas alucinadamente, para assim garantir imensos lucros no futuro aos compradores

\footnotetext{
${ }^{16}$ Nos escritos de Souto (2001, p. 30), a desestatização "é a retirada da presença do Estado de atividades reservadas constitucionalmente à iniciativa privada (princípio da livre iniciativa) ou de setores em que ela possa atuar com maior eficiência (princípio da economicidade); é o gênero, do qual são espécies a privatização, a concessão, a permissão, a terceirização e a gestão associada de funções públicas".
} 
- e sem que eles tivessem de enfrentar o risco de protestos e indignação do consumidor. Para as telefônicas, reajustes de até $500 \%$ [...]

O que o autor não revelou foi que as tarifas locais de telecomunicações, ${ }^{17}$ no final de 1995, apresentavam não apenas uma enorme defasagem em relação à evolução do nível de preços, resultado da utilização das tarifas e dos preços públicos para debelar o processo inflacionário nos anos anteriores, como também uma grande distorção, pois as elevadas tarifas de longa distância subsidiavam os serviços locais.

Uma comparação da tarifa brasileira em 1995 com algumas tarifas internacionais revelou grandes variações. A assinatura residencial no Brasil correspondia a $0,2 \%$ de sua renda per capita enquanto importava $1,7 \%$ na Argentina; 2,4\% no México; 0,6\% nos EUA; e uma média internacional de 2,2\%. A assinatura básica residencial mensal de US $\$ 0,63$, com uma franquia de 360 minutos, era a mais baixa do mundo, com exceção dos países que compunham a União Soviética. Apenas as ligações interurbanas e as internacionais apresentavam-se compatíveis com o referencial internacional (INTERNATIONAL TELECOMMUNICATION UNION, 1994, p. A31-A33).

O governo resolveu acabar com essas distorções. Em novembro de 1995, a assinatura residencial básica aumentou 512\%; a assinatura comercial, 80\%; o custo da ligação local subiu $79 \%$ e as tarifas interurbanas foram majoradas em 22\%. Em maio de 1997, mais um aumento: 209\% na assinatura residencial; 33\% na comercial; e 34\% nas ligações locais. Tais reajustes colocaram o país com tarifas extremamente compatíveis às tarifas de países com padrões de desenvolvimento semelhantes (NOVAES, 2000, p. 155-156).

Modificações precisavam igualmente ser implementadas no sistema de repartição de receitas. Até então o Ministério das Comunicações adotava um sistema em que a Embratel servia como um instrumento para transferir receitas das operadoras mais eficientes, e localizadas em regiões mais favorecidas economicamente, para as operadoras do Norte/Nordeste do país ou para companhias operacionalmente ineficientes, como a Telerj. ${ }^{18}$ Era

\footnotetext{
${ }^{17}$ O índice de inflação oficial adotado por Brasília somente incluía em seu cálculo as tarifas para os serviços locais, permitindo que as tarifas interurbanas e internacionais não sofressem restrição quanto à sua majoração pelos formuladores das políticas de estabilização.
}

A \& C R. de Dir. Administrativo e Constitucional, Belo Horizonte, ano 6, n. 25, p. 181-212, jul./set. 2006 
um sistema que não corrigia ineficiências, já que as empresas com desempenho operacional fraco acabavam retendo um percentual maior da receita de longa distância.

Após a privatização, de acordo com a Resolução Anatel no 33/97, as receitas oriundas das ligações interestaduais passaram a ser calculadas com lastro na remuneração dos meios (access fee) — um pagamento por minuto pelo uso da rede de outra operadora. ${ }^{19}$

\subsection{A Lei Geral de Telecomunicações}

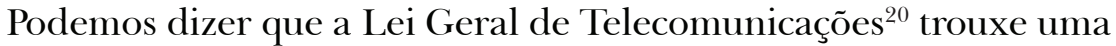
infinidade de transformações, como os conceitos, os princípios e os pressupostos de um novo modelo. Representou, na realidade, um marco em relação ao setor de telecomunicações: o Estado deixaria de exercer o papel de provedor dos serviços de telecomunicações, passando a regulá-los.

Em obediência às novas diretrizes estabelecidas no art. 21, inc. XI, da Constituição, a LGT determinou que competia à União organizar, por completo, a exploração dos serviços de telecomunicações, por intermédio do órgão regulador que viria a ser criado, e consoante as políticas públicas determinadas pelos Poderes Executivo e Legislativo. Para isso, seria preciso realizar, entre outros aspectos, o disciplinamento e a fiscalização da execução, comercialização e da implantação e funcionamento de redes de telecomunicação.

A LGT trouxe, ainda, uma nova classificação para os serviços de

\footnotetext{
${ }^{18}$ Assim, no exemplo dado por Novaes (2000, p. 156-157), "em uma ligação de longa distância doméstica de São Paulo para o Rio de Janeiro, a Telesp retinha, em 1997, 70,48\% desta receita, a Embratel os restantes $29,52 \%$ e a operadora do Rio de Janeiro não recebia nada para completar a chamada na sua rede. Para as chamadas internacionais recebidas no país, a Embratel ficava com $100 \%$ da receita. O percentual retido por cada operadora local e pela Embratel era revisto anualmente no mês de maio e aplicado retroativamente a $1^{\circ}$ de abril. A determinação do repasse das receitas levava em conta (entre outros fatores) a situação financeira da empresa, o retorno do investimento (seguindo as normas do Código de 1962, que assegurava uma remuneração mínima para as empresas) e a sua necessidade de financiamento. Assim, a Telesp e a Telesc transferiam cerca de $30 \%$ da receita de longa distância, enquanto a CRT, a CTBC e as operadoras de áreas menos favorecidas economicamente transferiam menos de 15\% para a Embratel".

19 "Além dessas mudanças, o governo se empenhava para melhorar a produtividade das empresas do Sistema Telebras através da redução de custos e do quadro de pessoal. [...] Um dos fatores que ajudaram a reduzir o custo médio por linha em serviço foi o aumento da produtividade, conforme mostra o indicador do número de linhas fixas em serviço por empregado: houve uma melhora de $46 \%$ entre 1994 e 1997. De fato, o número de empregados do Sistema Telebras diminuiu de 95,6 mil em 1994 para 87,3 mil em 1997, enquanto o número de linhas fixas em serviço aumentou de 11,2 milhões para 15,4 milhões" (NOVAES, 2000, p. 162).

${ }^{20}$ Coincidência ou não, em fevereiro de 1996, foi promulgada, nos EUA, a Telecommunication Act, em substituição ao Communications Act de 1934. Sua principal preocupação foi fomentar a competição e reduzir a ingerência governamental com o fulcro de assegurar preços mais baixos e melhor qualidade para os usuários (SCHIFER; PORTO, 2002, p. 69-70).
} 
telecomunicações; criou a Anatel; introduziu inovações no regime de licitações ${ }^{21}$ e no instituto da autorização, ao tratá-la não como um ato discricionário mas como um ato vinculado (art. 131, $\S 1^{\circ}$ ); e estabeleceu as bases para a reestruturação e para a privatização do Sistema Telebras (art. 186 e segs.).

Quanto às classificações dos serviços, a LGT adotou dois critérios distintos. O primeiro critério consiste na abrangência dos interesses a que os serviços atendem: i) serviços de interesse coletivo; e ii) serviços de interesse restrito (art. 62, caput).

Os serviços de interesse coletivo são aqueles cuja prestação deve ser proporcionada pela prestadora a qualquer interessado na sua fruição, consoante o art. 17 do Regulamento dos Serviços de Telecomunicações (RST). ${ }^{22} \mathrm{Já}$ os serviços de interesse restrito são aqueles que ou são ofertados de uma maneira seletiva, ou não são objeto de oferta comercial, como os serviços de telecomunicações desenvolvidos para utilização dentro de uma empresa.

A segunda classificação diz respeito ao regime jurídico de sua execução (art. 53, caput). Será público quando o serviço constituir obrigação legal da União, competência que deve ser executada mediante contrato de concessão ou ato de permissão (art. 163), atribuindo à prestadora a obrigação de universalização e de continuidade. Será privado quando a execução do serviço provier do exercício da liberdade de iniciativa do setor privado, bastando, para isso, uma autorização da Anatel (art. 131) e com obrigações apenas de expansão e atendimento.

De observar que o art. 64 apenas estabeleceu como competência econômica da União a exploração, mediante concessão ou permissão, do Serviço Telefônico Fixo Comutado (STFC), destinado ao uso do público em geral, em qualquer modalidade e âmbito.

O Poder Executivo, exercendo a competência do art. 18, I, da LGT instituiu, no art. $1^{\circ}$ do Decreto $\mathrm{n}^{\circ}$ 2.534/98, conhecido como Plano Geral de Outorgas (PGO), a prestação de STFC em três modalidades e âmbitos de serviço: i) o local; b) o de longa distância nacional; iii) o de longa dis-

\footnotetext{
${ }^{21}$ Marques Neto (2000, p. 314-315) mostra-nos que a concessão, na LGT, é um pouco diferente da concessão tradicional, por dois motivos. O primeiro deles refere-se ao equilíbrio econômico-financeiro, em cujo modelo tradicional todos os prejuízos são do Estado e todos os benefícios, da concessionária. No caso das empresas concessionárias de telefonia, esse equilíbrio é residual, já que apenas excepcionalmente ele incidiria de acordo com as hipóteses previstas contratualmente. A outra diferença diz respeito ao regime de reversão que no setor de telecomunicações, é muito mais restrito, limitando-se aos bens estritamente imprescindíveis à continuidade do serviço.

22 Aprovado pela Resolução Anatel n 73/98 (ANATEL, 1998).
}

A \& C R. de Dir. Administrativo e Constitucional, Belo Horizonte, ano 6, n. 25, p. 181-212, jul./set. 2006 
tância internacional. ${ }^{23}$

Uma grande inovação desse diploma legal foi o estabelecimento dos caminhos que deveriam ser trilhados pelo Estado na organização e na exploração dos serviços de telecomunicações, na medida em que atribuiu ao poder público o dever de: i) proporcionar o acesso às telecomunicações para toda a população mediante a estipulação de preços e de tarifas razoáveis e de qualidade (art. $2^{\circ}$, inc. I); ii) regular as atividades de telecomunicações, proporcionando oportunidades de investimento, estimulando o desenvolvimento tecnológico e, principalmente, adotando medidas ensejadoras de competição e de diversificação dos serviços (art. $2^{\circ}$, incs. III, IV e V).

A lei também estabeleceu quem tem a competência e o encargo de precisar como será o serviço de telecomunicação e o enquadramento específico de cada tipo de atividade, cada tipo de serviço, dentro da grade de classificação que ela introduz (MARQUES NETO, 2000, p. 305).

Essa classificação, por sua vez, foi realizada pelo Poder Executivo com a edição dos seguintes atos:

i) Plano Geral de Outorgas (PGO) - Decreto $\mathrm{n}^{\circ}$ 2.534/98, que estabeleceu as diretrizes do novo modelo de competição do setor, definindo os serviços a serem prestados em regime privado e em regime público. O Decreto previu um cronograma para a implementação do sistema concorrencial no setor e dispôs acerca das empresas a serem privatizadas, prevendo, ainda, a criação de outras empresas.

ii) Plano Geral de Metas de Universalização (PGMU), Decreto $\mathrm{n}^{\circ}$ 2.592/98, que estabeleceu diversos compromissos para as operadoras, como a densificação da oferta de serviço de telefonia e a ampliação do número de usuários.

iii) Plano Geral de Metas de Qualidade (PGMQ) - Resolução Anatel $n^{\circ} 30 / 98$, que definiu padrões de desempenho para as empresas de telecomunicações, respeitante à qualidade dos serviços prestados.

\footnotetext{
${ }^{23}$ Essas três modalidades de STFC constituem, hoje, o único serviço de telecomunicações explorado no regime público. Só que atualmente o STFC constitui objeto de execução concomitante em regime privado e em regime público, conforme prevêem o inc. III do art. 65 da LGT e o art. $1^{\circ}$, caput, do PGO. O princípio de concomitância dos regimes de prestação foi expressamente imposto às empresas desestatizadas, nos termos do art. 193 da LGT: "A desestatização de empresas ou grupos de empresas citadas no art. 187 implicará a imediata abertura à competição, na respectiva área, dos serviços prestados no regime público".
} 


\subsection{A atuação estatal por meio de uma nova estrutura: a Anatel}

Vimos que a Agência Nacional de Telecomunicações foi criada pela Lei $\mathrm{n}^{\circ} 9.472 / 97$ em seu art. $8^{\circ}$. A instalação se deu, por sua vez, com a edição do Decreto $n^{\circ}$ 2.338/97.

A agência, submetida a um regime autárquico especial, sujeita-se apenas às normas previstas na própria LGT, de maneira que não lhe é aplicável o regime geral das autarquias disposto no DL $n^{\circ}$ 200/67. A atuação da Anatel estaria, pois, vinculada aos mandamentos da Lei Geral de Telecomunicações e aos atos que a regulamentaram: o Decreto $\mathrm{n}^{\circ}$ 2.338/97 e o Regimento Interno da Agência (PORTO NETO, 2000, p. 287).

Na verdade, a instituição de um regime jurídico especial tem como escopo preservar a Anatel de ingerências indevidas até mesmo do Estado e de seus agentes e assim possibilitar "um espaço de legítima discricionariedade, com predomínio de juízos técnicos sobre as valorações políticas” (BARROS, 2003, p. 174).

Ainda com lastro em seu art. $8^{\circ}$, a LGT preconiza que a natureza de autarquia especial é caracterizada por independência administrativa; ausência de subordinação hierárquica; mandato fixo e estabilidade de seus dirigentes; e autonomia financeira. Por sua vez, o art. $9^{\circ}$ afirma, desde logo, que a agência atuará como uma autoridade administrativa independente. Com isto, fixam-se as bases para a atuação da Anatel.

$\mathrm{O}$ art. 50 da LGT, buscando dar autonomia financeira à Anatel, assegura-lhe a administração do Fundo de Fiscalização das Telecomunicações (FISTEL), composto, de acordo com o art. 51, por receitas de várias origens, como dotações orçamentárias, taxas de fiscalização e de funcionamento e as decorrentes do exercício do poder concedente dos serviços de telecomunicações.

A Anatel tem que submeter, anualmente, ao Ministério das Comunicações a sua proposta de orçamento, bem como a do FISTEL, as quais serão enviadas ao Ministério do Planejamento e Orçamento, para inclusão no projeto de lei orçamentária anual. O problema está, justamente, na execução dessa lei orçamentária, que pode ser contingenciada pelo governo com o objetivo de elevar o superávit do setor público.

O que deve ser ainda destacado é que a LGT atribui não à agência, mas ao Poder Executivo a tarefa de implementar, mediante decreto, uma série de medidas previstas no art. 18, como a instituição ou a eliminação da prestação de modalidade de serviço no regime público, concomitantemente ou não com sua prestação no regime privado (inc. I); a aprovação

A \& C R. de Dir. Administrativo e Constitucional, Belo Horizonte, ano 6, n. 25, p. 181-212, jul./set. 2006 
do plano geral de outorgas, para a definição quanto à divisão do país em áreas para exploração de serviços em regime de direito público, ao número de prestadoras para cada uma delas, aos prazos de vigência das concessões e aos prazos para admissão de novas prestadoras (inc. II); a aprovação do plano geral de metas de universalização do serviço de telecomunicações (inc. III) (OLIVEIRA, 2003, p. 86-90).

Além dessas atribuições, a LGT atribui ao Poder Executivo a competência de outorga dos serviços de radiodifusão sonora e de sons e imagens (art. 221, caput); nomeação de seus conselheiros (art. 23) e do seu ouvidor (art. 45, caput).

Após a definição da política de telecomunicações pelo Poder Legislativo e pelo Poder Executivo, dentro dos respectivos campos de competência, a Anatel tem a missão de implementá-la (art. 19, I). Nesse sentido, "em matéria de telecomunicações, todas as competências administrativas que não tenham sido atribuídas, por lei, ao Poder Executivo, estão reservadas à Anatel" (PORTO NETO, 2000, p. 288).

Uma importante previsão legal que consolida a independência da agência é o consignado no art. 19, XXV, da LGT, que atribui à agência a decisão em último grau sobre as matérias de sua alçada. Assim, cabe à Anatel decidir, por si só, as matérias que lhe competem, não sendo previsto recurso administrativo para nenhuma outra instância no âmbito do Poder Executivo.

\subsection{A telefonia celular e o início da abertura do setor com a venda das concessões da Banda B}

Ainda sob a presidência de José Sarney, foi introduzida legalmente no país uma nova tecnologia: a telefonia móvel celular. ${ }^{24} \mathrm{O}$ Decreto $\mathrm{n}^{\mathrm{o}}$ 96.618/1988 visava, antes de tudo, à possibilidade de excluir esse serviço do monopólio estatal previsto na Constituição para as telecomunicações, enquadrando-o na categoria de serviços públicos restritos. Em seguida, foi editada, pelo Ministério das Comunicações, a Portaria nº 06/89, que regulamentou o Serviço Móvel Terrestre Restrito Celular ou, simplesmente, o Serviço Móvel Celular e estabeleceu as faixas de freqüência

\footnotetext{
${ }^{24}$ De acordo com o art. $2^{\circ}, \S 1^{\circ}$, da Lei n 9.295/96, trata-se de serviço de telecomunicações móvel terrestre, que utiliza sistema de radiocomunicação com técnica celular, interconectado à rede pública de telecomunicações, e acessado por meios de terminais portáteis (telefones celulares) transportáveis ou veiculares, de uso individual.
}

A \& C R. de Dir. Administrativo e Constitucional, Belo Horizonte, ano 6, n. 25, p. 181-212, jul./set. 2006 
para o seu uso: as denominadas Bandas A e B.

A Portaria MINICOM n ${ }^{\circ} 376 / 92$ veio autorizar as operadoras estatais a explorarem o serviço celular e definiu as regras para que empresas privadas passassem a explorá-lo. No entanto, a primeira tentativa para conceder a exploração do serviço móvel ao setor privado, ainda em 1993, foi embargada por decisões judiciais. No ano seguinte, a abertura dessas atividades à iniciativa privada foi impossibilitada por pressões políticas do próprio Sistema Telebras e dos sindicatos de seus empregados (MARTINS, 1999, p. 42-43).

A partir da EC no 08/1995, o óbice jurídico à presença da iniciativa privada nas telecomunicações desapareceu. Temendo que a regulamentação de todo o setor demandasse longas discussões no Congresso Nacional, o Ministério das Comunicações resolveu tratar antes da liberalização do serviço celular por meio do que ficou conhecido como Lei Mínima das Telecomunicações, "mínima" porque possuía originariamente apenas oito artigos - Lei ${ }^{\circ}$ 9.295/96. Essa lei foi regulamentada pelo Decreto $\mathrm{n}^{\mathrm{o}}$ 2.056/96 (Regulamento SMC) e pela Portaria MINICOM $\mathrm{n}^{\mathrm{o}} 1.533 / 96$, e suas principais novidades foram: i) divisão do país em dez regiões para o serviço celular; ii) proposta de venda das concessões da chamada Banda B; iii) proposta de separação total das empresas de telefonia fixa e celular num prazo de dois anos..$^{25}$

A Lei Mínima fez com que as operadoras locais da Telebras separassem as atividades de telefonia fixa e celular, o que ocorreu em março de 1998. Do exposto, em vez de uma operadora de telefonia em cada estado, havia, no momento da privatização da Telebras, em julho de 1998, duas empresas em cada um: uma para o serviço fixo e outra para o serviço celular.

O governo estava livre, então, para promover o leilão da concessão do serviço móvel celular da Banda B. Assim, preocupado em evitar uma oligopolização do setor, dividiu o país em dez áreas para a concessão da Banda B da telefonia celular, organizadas de acordo com a atratividade de mercado das regiões aglutinadas, e separou essas áreas em duas categorias: uma que englobava as regiões mais favorecidas economicamente (as regiões de 1 a 6 ) e a segunda que abrangia as regiões menos favorecidas (de 7 a 10). Importa mencionar que o interessado em adquirir as concessões só poderia comprar uma empresa em cada um dos grupos.

\footnotetext{
25 Isto porque a exploração dos serviços de telefonia móvel foi iniciada pelas operadoras do Sistema Telebras na subfaixa de freqüência chamada Banda $A$.
}

A \& C R. de Dir. Administrativo e Constitucional, Belo Horizonte, ano 6, n. 25, p. 181-212, jul./set. 2006 
Em janeiro de 1997, após o anúncio do edital de concorrência pública, formaram-se catorze consórcios interessados nas diversas áreas disponibilizadas. Não obstante a ausência de proposta para a exploração dos serviços na região composta pelos estados do Amazonas, Pará, Maranhão, Amapá e Roraima, ${ }^{26}$ podemos afirmar que o leilão foi um sucesso, até porque se estava garantindo a esses vencedores apenas o direito de exploração do serviço e a utilização da faixa de radiofreqüência relativa à sua operação, não estando incluídas, na oferta, a infra-estrutura de transmissão ou a base de usuários. Registre-se que ágio total do leilão alcançou $237 \%$ do preço mínimo.

Vejamos alguns números. Na região metropolitana de São Paulo, o consórcio liderado pela BellSouth e o grupo Safra ofereceram 2,6 bilhões de reais pela licença ( $341 \%$ acima do preço mínimo) e, considerando a população residente na área de concessão, alcançou-se a quantia de US $\$ 156$ por habitante, valor até então recorde, quando comparado com a experiência internacional: US\$24/pop. no Equador (1993); US\$32/pop. na Espanha (1994) e US\$40/pop. nos Estados Unidos (1995). Para o interior de São Paulo, o consórcio formado pelo empresário Cecílio do Rego Almeida e pela empresa sueca Telia ofereceu 1,3 bilhões de reais (121\% de ágio). Já na região dos estados de Alagoas, Pernambuco, Ceará, Rio Grande do Norte e Paraíba, o ágio alcançou 141\% (ROCHA; FRIEDLANDER, 1997).

\subsection{A reestruturação e a privatização do sistema estatal de telefonia}

A LGT trouxe, em seu art. 186 e segs., todo um arcabouço respeitante à reestruturação e à desestatização das empresas estatais de telecomunicações. Martins (1999, p. 49) pontua que a Lei Geral atribuiu ao Poder Executivo a tarefa de reestruturar o Sistema Telebras mediante abertura à iniciativa privada, mas condicionada a uma série de regras capazes de prevenir o abuso do poder econômico e de assegurar a universalização dos serviços públicos de telecomunicações. As companhias assumiriam compromissos de garantir o acesso, pelos usuários, a seus serviços, a partir da cobertura de áreas economicamente pouco

\footnotetext{
${ }^{26}$ Não tendo havido interessados para essa região, uma nova licitação foi marcada para 21 de julho de 1998. Mais uma vez não houve pretendentes, o que levou o governo a marcar um novo certame para o mês seguinte, sem estipular um preço mínimo. Foi então que o consórcio formado pela Tele Centro-Oeste Celular, recém-privatizada e controlada pela Splice, e pela Inepar, acabou levando a concessão por 60 milhões de dólares (CORREA; MACHADO, 1998).
} 
atraentes.

Mister salientarmos que a LGT permitiu, por um lado, que o Executivo decidisse, como melhor entendesse, o arranjo geométrico da figura final, conferindo-lhe, para tanto, os necessários poderes de cisão, fusão, incorporação, dissolução e desativação de empreendimentos (art. 189, incs. I e II). Por outro lado, determinou uma série de limitações, elencadas por Xavier (2003, p. 49-50):

a) obrigação do cumprimento dos deveres constantes do art. $2^{\circ}$ LGT - art. 186 LGT - de que se destaca o interesse público em estimular o desenvolvimento tecnológico e industrial, em ambiente competitivo (inc. v);

b) imposição de deveres de universalização, unicamente às empresas desestatizadas, na sua qualidade de concessionárias (art. 199 LGT);

c) imposição da seguinte desconcentração de estruturas:

i) diferenciação do serviço público de STCF em três modalidades diferenciadas — arts. 64, parág. único, e 188 LGT e art. $1^{\circ}$, parág. 2º PGO;

ii) divisão do país em áreas de concessão com definição do número de prestadoras para cada uma delas e dos limites à respectiva atuação e condições de competição — arts. 71, 84 e 188 LGT e arts. 4 116 PGO;

iii) imediata implementação do princípio da concomitância do regime público e privado de exploração de uma mesma modalidade de serviço de telecomunicações - arts. 65, 66 e 193 LGT e art. 9 PGO;

iv) obrigação legal de separação estrutural entre o STFC e o SMC, com alienação em separado — arts. 187 e 194 LGT.

O Sistema Nacional de Telecomunicações foi então dividido em três grandes empresas de telefonia local fixa (Tele Norte-Leste, Telesp e Tele Centro-Sul), misturando áreas atraentes para investidores a outras que, certamente, ficariam encalhadas se fossem postas à venda sozinhas. Assim, quem ficasse com a Telerj e com a Telemig teria de levar, também, as empresas do Espírito Santo, de todo o Nordeste e de quatro estados da região Norte.

No pacote das regiões Centro-Oeste e Sul estavam as teles do Acre e de Rondônia. Quanto às empresas de telefonia celular, essas foram divididas em oito, de forma correspondente às áreas de concessão desse serviço de acordo com a Lei Mínima do serviço celular. A Embratel ficou para ser vendida isoladamente (GRIMBAUM, 1997).

É importante mencionar que apenas uma empresa em cada um dos grupos poderia ser adquirida pelo mesmo controlador. Diferentemente do leilão da telefonia celular, o governo não impôs qualquer restrição quanto à 
participação de estrangeiros no capital ou exigiu a presença de operadores de telefonia nos consórcios que iriam comprar a Telebras.

Em 29 de julho de 1998, às 14 h, os terminais da Bolsa de Valores do Rio de Janeiro registraram o término de uma época: todas as empresas do Sistema Telebras foram vendidas, com uma arrecadação de 22 bilhões de reais, um ágio de 63,7\% sobre o preço mínimo. Espanhóis, italianos, portugueses, americanos e japoneses foram os grandes vitoriosos desse processo, pois se tornaram controladores de 9 das 12 sub-holdings leiloadas num tempo recorde de 5 horas. Em 4 operadoras - Embratel, Telesp Celular, Tele Sudeste Celular e Tele Leste Celular —, a participação dos investidores internacionais foi de 100\% (DURÃO; MAGALHÃES, 1997).

Apresentamos a seguir uma consolidação daquele memorável leilão de 29 de julho de 1998 (BANCO ICATU; UNIÃO INTERNACIONAL DE TELECOMUNICAÇÕES apud DIEGUEZ; FRANÇA, 1998):

Pontual e perfeita na execução, a venda das teles enfrentou uma falha justamente na área mais problemática da telefonia, abrangendo as empresas do Sistema Telebras que mais precisavam de reestruturação, como as dos estados do Rio de Janeiro, Amazonas e Pará.

O governo não escondeu sua insatisfação com o consórcio, princi-

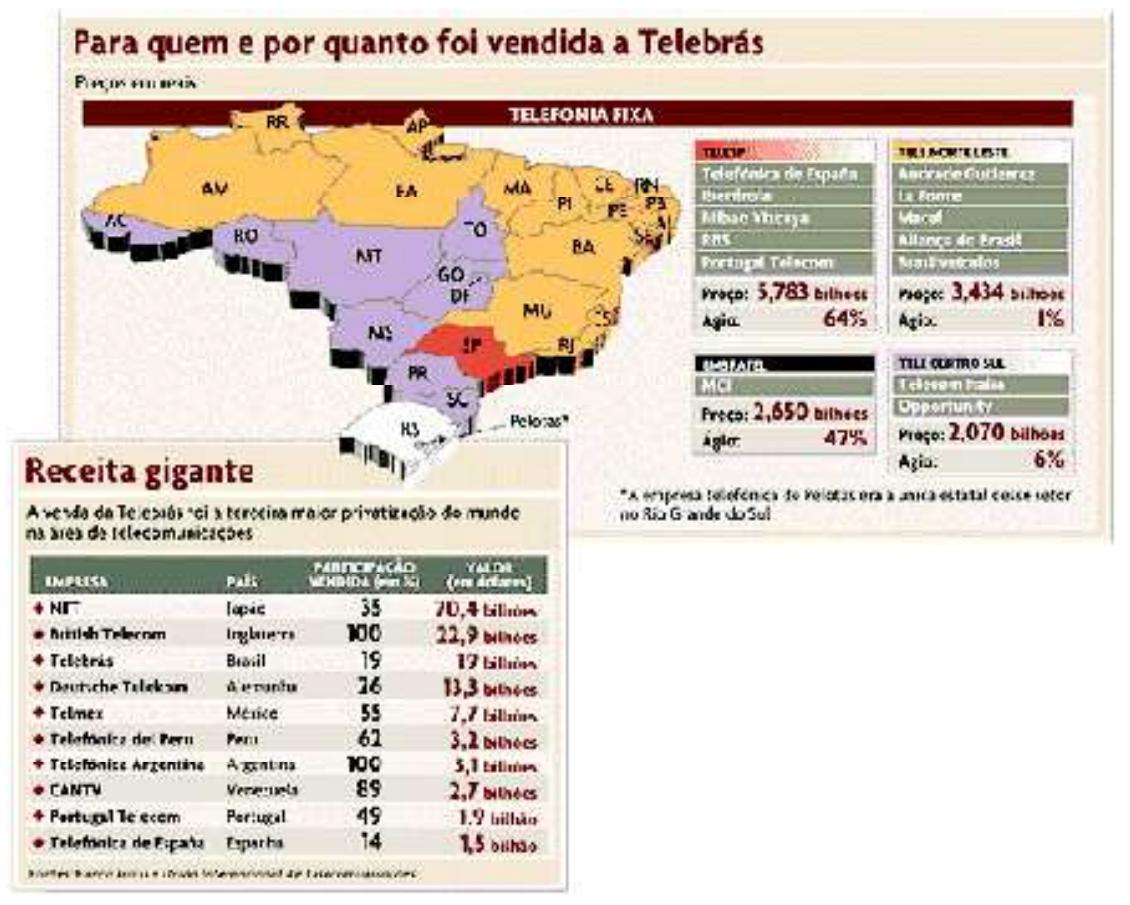

A \& C R. de Dir. Administrativo e Constitucional, Belo Horizonte, ano 6, n. 25, p. 181-212, jul./set. 2006 


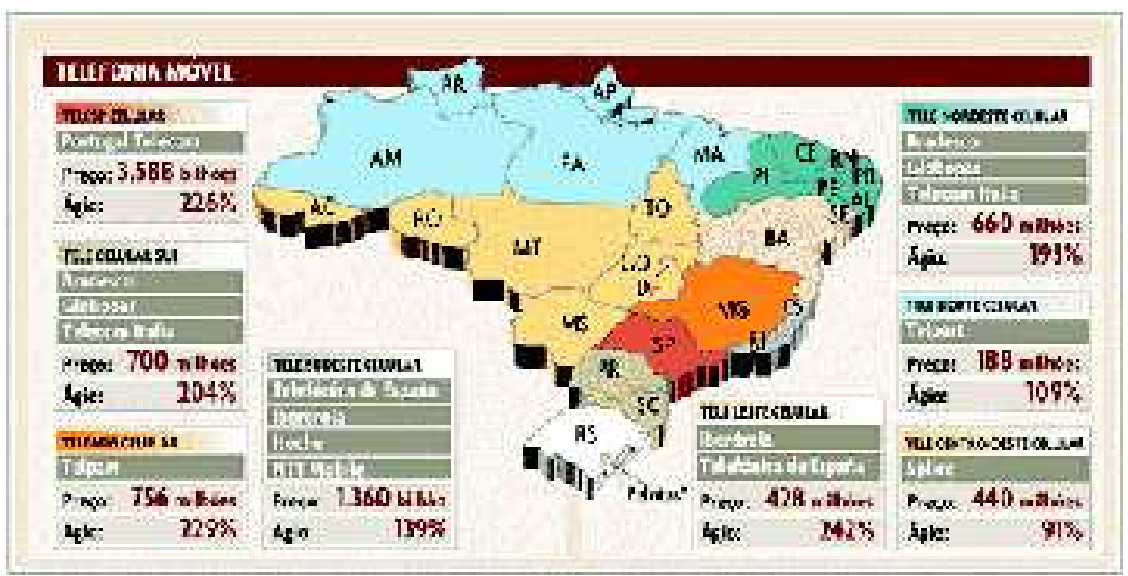

palmente porque nenhum dos participantes do consórcio vencedor, o Telemar, tinha experiência na operação de empresas telefônicas. Sem dinheiro suficiente para quitar sequer a primeira parcela da Tele Norte Leste, o BNDES comprou, 5 dias depois do leilão, 25\% do grupo Telemar, reassumindo o controle da Tele Norte Leste, ao realizar um acordo de acionistas que lhe dava o direito de veto em qualquer decisão (DIEGUEZ; PATURY, 1998).

\section{A privatização como instrumento de passagem do Estado empresário para Estado regulador}

A implantação do estatizante e centralizador Código de Telecomunicações de 1962, a criação da Embratel e o surgimento da Telebras refletem uma época em que, pelo menos no campo da intervenção estatal na economia, o Brasil vivia sob os auspícios de um Estado Social fortemente interventor.

Pouco tempo depois, no final dos anos 70, sob o influxo de diferentes fatores, nos quais se misturam razões pragmáticas com razões políticas e ideológicas (MEDAUAR, 2000, p. 105), o país se viu diante da necessidade de reduzir o tamanho do Estado:

Ainda que tendamos a crer que nossas dificuldades são o resultado das ações de um ou outro governo, o fato é que desde os anos 70, o mundo inteiro vive tempos turbulentos. Estamos todos imersos em uma complexa transição que envolve desde a base tecnológica até o marco institucional, passando por uma reestruturação profunda do aparelho produtivo em cada um dos países. (PÉREZ, 1999, p. 11) 
Não obstante o quadro que se desenhava, ainda não estava clara a estreita ligação entre a inflação persistente, a recessão econômica e o esgotamento do modelo de financiamento dos gastos públicos com a crise do Estado interventor e produtor de bens e serviços. Importa mencionar que a reação imediata à crise nos anos 80 foi no sentido de ignorá-la, seguida por uma proposta igualmente inadequada, no início do decênio seguinte, que consistia na retirada total do Estado das atividades socioeconômicas (FARIAS; RIBEIRO, 2002, p. 77).

Somente a partir de 1995 surgiu uma proposta consistente, com o desafio de superação da crise, passando o governo a ficar ciente dos limites existentes para atender aos crescentes déficits de serviços de infra-estrutura, essenciais ao desenvolvimento do país. Só que, com o aprofundamento da reflexão e do debate, chegou-se, também, a um consenso de que a solução não estava no desmantelamento do aparelho estatal, mas na sua reconstrução para torná-lo apto à assunção de novas atribuições.

Visando, então, à reestruturação do Estado, foi implementado um conjunto de medidas que envolviam a aceleração do processo de abertura econômica e das privatizações, a estabilidade da moeda, um ajuste fiscal e uma ampla reforma institucional do Estado (QUEIROZ; PRADO FILHO, 2002, p. 101).

As modificações postas em prática apresentaram, como característica principal, a redução do papel do Estado como produtor de bens e serviços, bem como um aumento na sua função reguladora:

A reforma do Estado deve ser entendida dentro do contexto da redefinição do papel do Estado, que deixa de ser responsável pelo desenvolvimento econômico e social pela via da produção de bens e serviços, para fortalecer-se na função de promotor e regulador desse desenvolvimento. (BRASIL, 1995, p. 12)

Cassagne (2004, p. 362, tradução nossa), analisando a década de 1990 no contexto argentino, revela-se pertinente:

Conseqüentemente, o papel do Estado nesse novo modelo não mais é o de produtor de bens nem o de gestor de serviços públicos. Sua principal função, nesse âmbito da economia, passou a se concentrar tanto na regulação do controle dos serviços e atividades de interesse público (naquilo que diz respeito à qualidade e à eficiência na prestação dessas atividades) como na promoção da concorrência que se efetiva, igualmente, mediante regulações estatais.

Como visto alhures, os serviços estatais de telecomunicações no Brasil serviram de instrumento de políticas públicas desde o final da década 
de 1970 até o início dos anos 90, apresentando-se incapazes de acompanhar as mudanças tecnológicas profundas por que passava tal setor no mundo, o que exigiria investimentos vultosos, que o Estado, comprometido com outros objetivos, não estava disposto a realizar.

A privatização do Sistema Nacional de Telecomunicações revelouse a melhor das alternativas naquele contexto, além de ter sido insistentemente recomendada por instituições internacionais.

Em artigo publicado no ano da privatização da Telebras pelo Banco Mundial - organismo que propiciou e financiou diversos processos de privatização em toda América Latina -, há um relato dos benefícios que supostamente adviriam caso o processo de alienação das empresas estatais iniciasse com a operadora monopólica dos serviços de telecomunicações. Tal estudo, cujo título "O papel da nau capitânia das privatizações das telecomunicações" é bastante ilustrativo, destaca o caráter estratégico que adquiriu a venda do monopólio estatal das telecomunicações (KHAMBATO, 1998 apud ABELES; FORCINITO; SCHORR, 2001, p. 27).

A efetivação da privatização das telecomunicações fez com que o papel do Estado mudasse nesse setor. Ao deixar de oferecer tais serviços, não poderia entregá-los às próprias forças do mercado, porquanto era estratégico demais para o país, um bem de consumo essencial na sociedade de informação em que vivemos. Importa anotar que as próprias empresas privatizadas exigiam um ambiente regulatório redutor de riscos e propício à auferição de lucros.

Dessa forma, impunha-se a necessidade de estabelecer regulações capazes de eliminar o risco de conversão de monopólios estatais em monopólios privados, ${ }^{27}$ buscando-se assim favorecer o princípio da livre concorrência e a proteção do cidadão-usuário desses serviços (GUIMARÃES, 2002, p. 258-259).

O novo modelo passou a reconhecer que apenas as forças de mercado seriam insuficientes para garantir a adequada prestação de serviços. A atuação estatal por intermédio de instrumentos jurídicos que, entre outras atribuições, estimulassem a concorrência e coibissem a

\footnotetext{
27 O caso argentino é emblemático: "Como resultado do desenho regulatório do processo de privatização da ENTel, os consórcios controladores das empresas Telecom Argentina SA e Telefónica de Argentina SA, que obtiveram as licenças - com exclusividade — para a prestação do serviço básico telefônico nas zonas Norte e Sul do país, respectivamente, tornaram-se adjudicatórios conjuntamente e em partes iguais das empresas Telintar SA (serviços de chamadas internacionais) e Startel SA (serviços em concorrência). Dessarte, o modelo de estrutura de mercado emergente da privatização da ENTel determinou a presença de duas
} 
concentração do poder econômico revelava-se decisiva. Daí o papel do Estado regulador em suprir, por meio de normas, como as que impõem obrigações de universalização e de qualidade nos serviços de telecomunicações, as deficiências do mercado (LAENDER, 2002, p. 41-42).

É importante termos claro que a retirada do Estado da prestação direta dos serviços públicos não implicou o seu enfraquecimento. Isso porque, ao assumir a função regulatória, acabou o Estado incrementando suas atividades: o poder público passou a ser o fomentador da atividade, o fiscalizador da prestação, o árbitro de conflitos, o sancionador das prestadoras, o definidor de marcos estratégicos. Trata-se, na verdade, como bem aduz Pessoa (2003, p. 54), de uma modalidade de Estado social que intervém indiretamente, mediante a utilização da competência normativa, naquelas atividades econômicas afetadas por algum interesse público. Ou ainda um Estado social-liberal como pontifica Pereira (2002, p. 20): "[...] é social-liberal porque acredita no mercado como um excelente, mas imperfeito, agente de alocação de recursos".

Nesse contexto é que deve ser entendido o processo de reforma da prestação de serviços de telecomunicação no Brasil. A Emenda Constitucional $n^{\circ}$ 08/95, a edição da Lei Geral de Telecomunicações, o Plano Geral de Outorgas e o Plano Geral de Metas de Universalização comprovam o que Chevallier (2004, p. 53, tradução nossa) vem arrematar sobre ao assunto:

O Estado permanece presente na economia não mais como um piloto, mas como um estrategista, que se esforça por acompanhar ou amortecer o efeito de movimentos sobre os quais não tem mais controle: o estabelecimento de uma economia aberta priva-o de seus meios de ação clássicos e nega-lhe qualquer possibilidade de definição de um projeto de desenvolvimento. Da mesma maneira, a lógica concorrencial que comanda o funcionamento das atividades produtivas leva ao desmantelamento de suas estruturas tradicionais.[...] No entanto, esse refluxo da concepção que erigiu o Estado em motor do desenvolvimento, confiando-lhe a gestão de setores-chaves da economia não é sinônimo de descompromisso: o Estado aparece como um regulador, encarregado de garantir o equilíbrio de todo um sistema. A evolução da economia de mercado tornou essa intervenção indispensável: a complexidade crescente dos circuitos econômicos, as mutações tecnológicas, a sofisticação dos produtos financeiros, a globalização do comércio, mas também a pressão crescente do poder econômico, cuja influência aumenta com a globalização, impõem o surgimento de uma instância capaz de fixar certas regras do jogo, de fazer prevalecer um disciplinamento, de proteger determinados interesses.

\section{Referências}

A \& C R. de Dir. Administrativo e Constitucional, Belo Horizonte, ano 6, n. 25, p. 181-212, jul./set. 2006 
ABDO, M. Dilema das operadoras. Gazeta Mercantil, São Paulo, 4 fev. 2005, p. A2.

ABELES, M.; FORCINITO, K.; SCHORR, M. El mascarón de proa del proceso de privatizaciones. In: ABELES, M.; FORCINITO, K.; M. SCHORR. El olipopolio telefónico argentino frente a la liberalizacion del mercado. Bernal: Universidad Nacional de Quilmes, 2001. p. 27-49.

ANATEL. Projeto de Lei Geral das Telecomunicações, Ministério das Comunicações, Brasília, 1996. Disponível em: <http://www.anatel.gov.br/index.asp?link=/biblioteca/Publicacao/ Diretizl.htm?Cod=1979>. Acesso em: 28 jan. 2005.

Resolução Anatel $n^{\circ}$ 73, Brasília, 25 de novembro de 1998. Disponível em: <http://www.anatel.gov.br/index.asp?link=/biblioteca/resolucao/1998/res_73_1998. htm?Cod=25T $>$. Acesso em: 20 maio 2004.

Museu do telefone. Brasília, [ca. 2000]. Disponível em: <http://www.anatel.gov.br/ biblioteca/Publicacao/museu_telefone $>$. Acesso em: 15 jan. 2005.

BAER, W. O extenso setor público brasileiro. In: NEUHAUS, P. (Coord.). Economia brasileira. Uma visão histórica. Rio de Janeiro: Campus, 1980. p. 387-410.

BARROS, L. R. Agências reguladoras. Constituição, transformações do Estado e legitimidade democrática. In: MOREIRA NETO, D. F. (Coord.). Uma avaliação das tendências contemporâneas do Direito Administrativo. Rio de Janeiro: Renovar, 2003.

BIONDI, A. O Brasil privatizado. Um balanço do desmonte do Estado. São Paulo: Fundação Perseu Abramo, 2000.

BRASIL. Plano diretor da reforma do aparelho do Estado. Ministério da Administração Federal e Reforma do Estado, novembro de 1995. Disponível em: <http://www.planalto.gov.br>. Acesso em: 15 nov. 2004.

BRITO, M. Subsídios para a história da telefonia no Brasil. Rio de Janeiro: NEC, 1976.

CAMPOS, F. R. A fase dos dinossauros ou os gigolôs da viúva. O Estado de São Paulo, São Paulo, 5 mar. 1995, p. A2.

CASSAGne, J. C. Derecho administrativo. Buenos Aires: Depalma, 2004. v. 1.

CHEVALLIER, J. L'État post-moderne. Paris: LGDJ, 2004.

CORREA, M.; MACHADO, S. Splice e Inepar arrematam banda B. Gazeta Mercantil, São Paulo, 20 out. 1998, p. B4.

COSTA, T. Privatização rompe barreira do atraso. Gazeta Mercantil, São Paulo, 7 de out. 2002. Disponível em: < http://www.investnews.com.br/BancoNoticias/default.asp>. Acesso em: 31 jan. 2005 .

CRUZ, P. D. Dívida externa e política econômica: a experiência brasileira nos anos setenta. São Paulo: Brasiliense, 1984.

empresas operando monopolicamente (sob um regime de exclusividade) em suas respectivas áreas de licença, que ademais conservaram (em conjunto) o monopólio das chamadas de longa distância nacional e internacional-, já que se viram favorecidas pela possibilidade, concedida pelo próprio marco normativo, de participar dos segmentos competitivos do mercado (como é o caso da transmissão de dados). Só que tal desenho institucional (o da estrutura do mercado local de telecomunicações pósprivatização) contradiz as experiências e recomendações internacionais na matéria, e desconhece as exigências regulatórias concernentes à introdução de pressões competitivas em mercados em que preexistiam operadores monopólicos" (SCHORR, 2001, p. 161-162, tradução nossa).

A \& C R. de Dir. Administrativo e Constitucional, Belo Horizonte, ano 6, n. 25, p. 181-212, jul./set. 2006 
DIAS, J. A. Telefonia atrai investidor externo. Folha de S.Paulo, São Paulo, 11 jan. 2004, p. B3.

DIEGUEZ, C.; FRANÇA, R. 22 bi no bolso. Veja, São Paulo, 05 ago. 1998. Disponível em: <http://veja.abril.com.br/050898/p_040.html>. Acesso em: 30 jan. 2005.

DIEGUEZ, C.; PATURY, F. Um abacaxi na linha. Veja, 12 ago. 1998. Disponível em: < http:// veja.abril.com.br/120898/p_116.html>. Acesso em: 30 jan. 2005.

DURÃO, V. S.; MAGALHÃES, H. Privatização das teles rende R\$22 bilhões. Gazeta Mercantil, São Paulo, 30 jul. 1997, p. Al.

FARIAS, P. C. L.; RIBEIRO, S. M. R. Regulação e os novos modelos de gestão no Brasil. Revista do Serviço Público, Brasília, a. 53, n. 3, p. 77-92, jul./set. 2002.

FIECHTER, G. A. Brazil since 1964: modernisation under a military régime. A study of the interactions of politics and economics in a contemporary military régime. New York: Halsted Press, 1972.

FIORATI, J. J. As telecomunicações nos direitos interno e internacional: o direito brasileiro e as regras da OMC. Rio de Janeiro: Renovar, 2004.

FURTADO, M. B. Síntese da economia Brasileira. Rio de Janeiro: LTC, 2000.

GRIMBAUM, P. Oferta gigante. Veja, 29 out. 1997. Disponível em: < http://veja.abril.com. br/291097/p_122.html>. Acesso em: 30 jan. 2005.

GUIMARÃES, C. H. C. Análise do processo de privatização e da regulamentação do setor de telecomunicações: o caso do Rio Grande do sul. Caderno de pesquisa discente / Faculdade de Direito Ritter dos Reis, Porto Alegre, n. 2, p. 253-267, 2002.

IANNI, O. Estado e planejamento econômico no Brasil. 5. ed. Rio de Janeiro: Civilização Brasileira, 1986.

INTERNATIONAL TELECOMMUNICATION UNION. World telecommunication development report. Genebra: International Telecommunication Union, 1994.

LAENDER, G. B. Interconexão, "unbundling” e compartilhamento de meios de redes de telecomunicação. Revista de Informação Legislativa, Brasília, a. 39, n. 154, p. 41-49, abr.jun. 2002.

LEHFELD, L. S. As novas tendências na regulamentação do sistema de telecomunicações pela Agência Nacional de Telecomunicações - Anatel. Rio de Janeiro: Renovar, 2003.

LESSA, C. 15 anos de política econômica. São Paulo: Brasiliense, 1983.

MARQUES NETO, F. A. Direito das telecomunicações e a ANATEL. In: SUNDFELD, C. A. (Coord.). Direito administrativo econômico. São Paulo: Malheiros, 2000. p. 300-316.

MARTINS, M. A. O Brasil e a globalização das comunicações na década de 90. Dissertação (Mestrado em Relações Internacionais) - UnB, Brasília, 1999.

MAZZA, M. Número de aparelhos cresce 41,47\% em 2004. Gazeta Mercantil, São Paulo, 18 jan. de 2005, p. A-12.

MEDAUAR, O. Direito administrativo moderno. São Paulo: RT, 2000.

MOTTER, P. A batalha invisível da Constituinte: interesses privados versus caráter público da radiodifusão no Brasil. Dissertação (Mestrado em Ciência Política) - UnB, Brasília, 1994.

NOVAES, A. Privatização do setor de telecomunicações no Brasil. In: PINHEIRO, A. C.;

FUKASAKU, K. A privatização no Brasil. O caso dos serviços de utilidade pública. Rio de Janeiro: BNDES, FINAME, BNDESPAR, 2000. p. 145-177.

OLIVEIRA, A. P.; CARVALHO, S. Visão do futuro da telefonia fixa. Gazeta Mercantil, São

A \& C R. de Dir. Administrativo e Constitucional, Belo Horizonte, ano 6, n. 25, p. 181-212, jul./set. 2006 
Paulo, 3 nov. 2003, p. A3.

OLIVEIRA, F. A economia brasileira: crítica à razão dualista. 4. ed. Rio de Janeiro: Vozes, 1981.

OLIVEIRA, P. C. Agências reguladoras brasileiras: dos limites legais à independência normativa da função reguladora. Dissertação (Mestrado em Direito Público) - UFPE, Recife, 2003.

ORTIZ, G. A. Economía Y Estado. Buenos Aires: Abeledo-Perrot, 1993.

PATURY, F.; FERREIRA, R. Caiu a ficha: o governo coloca para rodar o bilionário processo de venda das estatais telefônicas. Veja, 25 jun. 1997. Disponível em: < http://veja.abril.com. br/250697/p_110.html>. Acesso em: 31 jan. 2005.

PEREIRA, L. C. B. Reforma da nova gestão pública: agora na agenda da América Latina, no entanto... Revista do Serviço Público, a. 53, n. 1, p. 5-27, jan./mar. 2002.

PÉREZ, C. El reto del cambio de paradigma tecnoeconómico. Revista BCV, Caracas, v. 13, n. 2, p. 09-25, 1999.

PESSOA, R. S. Administração e regulação. Rio de Janeiro: Forense, 2003.

PINHEIRO, A. C.; GIAMBIGI, F. Os antecedentes macroeconômicos e a estrutura institucional da privatização no Brasil. In: PINHEIRO, A. C.; FUKASAKU, K. A privatização no Brasil. O caso dos serviços de utilidade pública. Rio de Janeiro: BNDES, FINAME,

BNDESPAR, 2000. p. 13-44.

PINHEIRO, A. C. Regulatory reform in brazilian infrastructure: where do we stand? Texto para Discussão, Brasília: IPEA, n. 964, jul. 2003.

PLANE, P. La privatisation dans le pays en développement: qu'avons-nous appris? Révue Française d'Économie, v. 9, n. 2, p. 37-58, 1994.

POR QUE vender a Telebrás. Veja, 29 de jul. 1998. Disponível em: < http://veja.abril.com. br/290798/p_009.html>. Acesso em: 31 jan. 2004.

PORTO NETO, B. A Agência Nacional de Telecomunicações. In: SUNDFELD, C. A. (Coord.). Direito administrativo econômico. São Paulo: Malheiros, 2000. p. 286-299.

QUEIROZ, R. B.; PRADO FILHO, K. Agências reguladoras: um referencial teórico para o entendimento de seu papel no ambiente atual. Revista Paranaense de Desenvolvimento, Curitiba, n. 103, p. 101-119, jul./dez. 2002.

ROCHA, L.; FRIEDLANDER, D. Uma aposta de 2,6 bilhões. Veja, 16 de julho de 1997. Disponível em: <http://veja.abril.com.br/160797/p_112.html>. Acesso em: 30 jan. 2005.

SCANTIMBURGO, J. História do liberalismo no Brasil. São Paulo: LTR, 1996.

SCHIFER, C.; PORTO, R. Telecomunicaciones. Marco regulatorio. Buenos Aires: El Derecho, 2002.

SCHORR, M. La centralización del capital: consolidación del oligopolio telefónico y grupos multimedia. In: ABELES, M.; FORCINITO, K.; SCHORR, M. El oligopolio telefónico argentino frente a la liberalización del mercado. Bernal: Universidad Nacional de Quilmes Ediciones, 2001. p. 135-228.

SOUTO, M. J. S. Desestatização - privatização, concessões e terceirizações. Rio de Janeiro: Lumen Juris, 2001.

SUNDFELD, C. A. nova regulação estatal e as agências independentes. In: SUNDFELD, C. A. (Coord.). Direito administrativo econômico. São Paulo: Malheiros - SBDP, 2000. p. 72-98. 
TAVARES, M. C. Da substituição das importações ao capitalismo financeiro. Rio de Janeiro: Zahar, 1972.

VASCONCELLOS, M. A. S. Economia brasileira contemporânea. São Paulo: Atlas, 1999.

VENÂNCIO FILHO, A. A intervenção do Estado no domínio econômico. Rio de Janeiro: FGV, 1968.

VIANNA, G. Privatização das telecomunicações. Rio de Janeiro: Notrya, 1993.

WERNECK, R. L. F. Empresas estatais e política macroeconômica. Rio de Janeiro: Campus, 1993.

XAVIER, H. A. L. O regime especial da concorrência no direito das telecomunicações. Rio de Janeiro: Forense, 2003.

Informação bibliográfica deste texto, conforme a NBR 6023:2002 da Associação Brasileira de Normas Técnicas (ABNT):

COELHO, André Felipe Canuto. As cambiantes relações entre o Estado brasileiro e o setor de telefonia. A\&C Revista de Direito Administrativo e Constitucional, Belo Horizonte, ano 6, $n$. 25, p. 181-212, jul./set. 2006.

A \& C R. de Dir. Administrativo e Constitucional, Belo Horizonte, ano 6, n. 25, p. 181-212, jul./set. 2006 